\title{
Discovering Shadow Lines and their effects on Nationalist Identity in Amitav Ghosh's The Shadow Lines
}

\author{
Pragya Dhiman
}

Department of English, University of Delhi, India

Received: 02 Apr 2021; Received in revised form: 07 May 2021; Accepted: 29 May 2021; Available online: 14 Jun 2021 (C2021 The Author(s). Published by Infogain Publication. This is an open access article under the CC BY license (https://creativecommons.org/licenses/by/4.0/).

\begin{abstract}
A brilliantly affecting novel, The Shadow Lines penned by the Sahitya Akademi Award winner, Amitav Ghosh, reflects the trepidation and anxieties of its protagonist in a manner, which relates to the fragmented associations one has with their identity and their sense of nationalism. This paper explores the question of identity one has within the boundaries of these imaginary lines and how they affect the sense of nationalism in the body of the people immured by them.
\end{abstract}

Keywords - Imagination, lines, memory, nationalism.

\section{INTRODUCTION}

Through an account of his family history, the narrator of Amitav Ghosh's The Shadow Lines is exposing how nations are created on arbitrary grounds with boundaries and lines which do not possess any material existence; just mere shadows alluding to the sense of segregation. His search for meaning through his memories blatantly portrays the politics as well as the communal divisions, fatal chasms, which mar the imagined state of nation. When we talk about imagination playing a key role in the formation of a nation, we are questioning how citizens recognize themselves with a particular nationality, for with stark differences comes disunity and charged tensions, as we see playing out in the riots of 1964, crafted with ease by Ghosh, which occurred in Khulna across the border from Calcutta, in which Tridib loses his life, a poignant account which the narrator is determined to not let vanish in the shadows of human memory. Yet, at the same time, we see a sense of unity in the riots of 1963 in which 'Muslims, Sikhs and Hindus alike took part', and what is interesting to note is how the theft of an ancient relic brought the people of Kashmir together in a manner which would be called nationalistic in nature, but they have their collective effort branded as otherwise,

"But the targets of the rioters

(and with what disbelief we

\begin{abstract}
read of this today) were not people- neither Hindus, not Muslims, nor Sikhs- but property identified with the government and the police. The government blamed these attacks on 'anti-national elements.", (The Shadow Lines, 248)
\end{abstract}

The title, The Shadow Lines in itself insinuates the intangibility of the 'lines' which separate various territories from one another: States are separated by these lines, Nations are separated by these lines, Continents are separated by these lines, but how do these incorporeal lines exist without any geographical marks of their substance? Are they just mere shadows, faint ideas? We see the same questions being raised by the narrator's grandmother Th'amma with perturbation as she exclaims, bordering on indignation,

\footnotetext{
"But if there aren't any trenches or anything, how are people to know? I mean, where's the difference then? And if there's no difference both sides will be the same; it'll be just like it used to before, when we used to
} 
catch a train in Dhaka and get off in Calcutta the next day without anybody stopping us. What was it all for thenpartition and all the killing and everything-if there isn't something in between?" (The Shadow Lines, 167)

These shadow lines are meant to draw distance between different nations, to cement the idea of a palpable distinction that speaks of the variance in humans, but are we really that different from one another? Anita Desai in her review of the The Shadow Lines states, "He[Amitav Ghosh] does not have any interest in painting different worlds for us-on the contrary, he makes them so similar that one has scarcely any sense of passing from one culture over the border into another." This statement aptly captures the essence of the title; these different worlds across invented borders are nothing but reflections of one another, mirrors, simply expressing the same human frailties,

\begin{abstract}
"What they had felt, I wondered, when they discovered that they had created not a separation, but a yetundiscovered irony - the irony that killed Tridib: the simple fact that there had never been a moment in the four-thousandyear-old history of that map, when the places we know as Dhaka and Calcutta were more closely bound to each other than after they had drawn their lines - so closely that I, in Calcutta, had only to look into the mirror to be in Dhaka; a moment when each city was the inverted image of the other, locked into an irreversible symmetry by the line that was to set us free - our looking-glass border." (The Shadow Lines, 257)
\end{abstract}

These lines exist in the shadows of imperfect memories, history of the people and the land they inhabit. The book itself is divided into two parts: Going Away and Coming Home, communicating the movement from and to a place, coming and going, expressing 'a journey that was a search for precisely that fixed point which permits the proper use of verbs of movement'. The identity of a person is deeply rooted in their sense of nationalism. To the narrator it seemed as if "there were only states and citizens; there were no people at all." Memory plays a huge role in determining a people's attachment to their nation, for once you cross those invisible lines that demarcate one place from another, you are changing how you identify yourself. That is the power of these lines; these shadow lines, that are imperceptible to the eye, but not insignificant to the mind, as verbalized by Jethamoshai,

“Once you start moving you
never stop. That's what I told
my sons when they took the
trains. I said: I don't believe in
this India-Shindia. It's all very
well, you're going away now,
but suppose when you get there
they decide to draw another line
somewhere? What will you do
then? Where will you move to?
No one will have you anywhere.
As for me, I was born here, and
I'll die here." (The Shadow
Lines, 237)

The importance of imagination is indisputable in the novel throughout. Traveling from place to place, without physically leaving is highlighted, as the narrator grapples with the truth of his London and the reality of Ila's. When we talk about crossing borders to come and go, we see the narrator contesting the substantiality of these lines and these places, 'I could not persuade her that a place does not merely exist, that it has to be invented in one's imagination...' So when we talk about inventing a place, we are also indicating the distinction of that place from other regions, separated by invented lines and immured by invented borders.

Meenakshi Mukherji comments on the novel saying, "Amitav Ghosh would like to believe in a world where there is nothing in between, where borders are illusions Actually three countries get interlocked in Amitav Ghosh's Shadow Lines-East Pakistan before it became Bangladesh, England, and India-and people of at least three religions and nationalities impinge upon one another's lives and deaths. It is very much a text of our times when human lives spill over from one country to another, where language and loyalties cannot be contained within tidy national frontiers." The title The Shadow Lines begs us to raise the question then, why and how do these lines exist? There is a sense of desperation in the beliefs one holds about these borders and the certainty they provide, a sustainable reality, even if it is a false facade, as signified by the narrator, 'I believed in the reality of space; 
I believed in the reality of nations and borders; I believed that across the border there existed another reality.'

Imaginations, shadows and memories, The Shadow Lines maps the suffocating deliberations humans have regarding their identity, how abstract ideas and concepts shape crucial aspects of life and how mere lines enchant us into believing there is order in a chaotic universe,
"When I turned back to my first
circle I was struck with wonder
that there had really been a
time, not so long ago, when
people, sensible people, of good intention, had thought that all maps were the same, that there was a special enchantment in lines; I had to remind myself that they were not to be blamed for believing that there was something admirable in moving violence to the borders and dealing with it through science and factories, for that was the pattern of the world. They had drawn their borders, believing in that pattern, in the enchantment of lines, hoping perhaps that once they had etched their borders upon the map, the two bits of land would sail away from each other like the shifting tectonic plates of the prehistoric Gondwanaland." (The Shadow

Lines, 256-257)

\section{CONCLUSION}

The title The Shadow Lines is exact in communicating what Amitav Ghosh wishes to convey, for it is not just a story about a family's history, but it is a story challenging the preset notions we have come to accept as reality, questioning the borders and lines that we have come to accept as actuality in this broken world of obscure identities and fraudulent nationalism.

\section{REFERENCES}

[1] Desai, Anita. Choosing to Inhabit in the Real World. Taylor and Francis Ltd. Third World Quarterly, Vol. 11, No. 2 (Apr., 1989), pp. 167 - 169, 1989.

[2] Butt, Nadia. Inventing or Recalling the Contact Zones? Transcultural Spaces in Amitav Ghosh's The Shadow Lines. Postcolonial Text, Vol. 4, No. 3 (2008), 2008
[3] Ghosh, Amitav. The Shadow Lines. India, Penguin Random House Pvt. Ltd, 2019. 